\title{
Renal Cell Carcinoma with Constitutional Chromosome 3 Translocations
}

National Cancer Institute

\section{Source}

National Cancer Institute. Renal Cell Carcinoma with Constitutional Chromosome 3

Translocations. NCl Thesaurus. Code C39790.

A renal cell carcinoma with constitutional chromosome 3 translocations. 